\title{
APLIKASI PROGRAM LINEAR DALAM PEMBUATAN FORMULASI COOKIES DARI TEPUNG KOMPOSIT (JAGUNG, KACANG KEDELAI DAN BONGGOL PISANG BATU)
}

\author{
Applications of Linear Programs in Making Cookies Formulation of Composite Flour \\ (Corn, Soybeans, and Banana Stone Hump) \\ Hari Hariadi1 ${ }^{1, *}$, Supli Effendi ${ }^{2}$, Nana Sutisna Achyadi \\ ${ }^{1}$ Jurusan Ilmu dan Teknologi Pangan, Fakultas Pertanian \\ Universitas Garut, Garut \\ ${ }^{2}$ Jurusan Teknologi Pangan, Fakultas Teknik \\ Universitas Pasundan, Bandung \\ Email ${ }^{*}$ : raden_harie@yahoo.com
}

Diterima: 2 Januari 2017

Disetujui: 25 Februari 2017

\begin{abstract}
Objective of this research was to study the formulation of composite flour by optimizing the use of raw materials without reducing the quality of product. Method used was the application of linear programming. The limiting factor was the ratio of raw material of composite flour, where the value taken from SNI No. 012973-1992. The constraint factor was the price of used raw materials. Results from the first phase of research produces flour characteristics that in accordance with ISO quality requirements. The chemical analysis for corn flour was $70.45 \%$ carbohydrate, $8.96 \%$ protein, $4.00 \%$ fat, and $3.14 \%$ moisture content; soy bean flour contains $37.80 \%$ carbohydrates, $35.60 \%$ protein, $20.16 \%$ fat, and $2.83 \%$ moisture content; while the banana hump flour contains $66.20 \%$ carbohydrate, $3.40 \%$ protein, $0,00 \%$ fat, and $9.28 \%$ moisture content. The result from the second phase research showed that of the five feasible formulations, formulation 5 was the chosen optimum formula. Based on hedonic test, it produced cookies with the best color, taste, flavor and texture. Based on linear program, it had the lowest production cost of Rp 1734.400,- per $100 \mathrm{~g}$; based on the analysis of nutrient content using linear programming, formulation 5 contains 6.80 grams protein, 55.03 grams carbohydrate, $16.50 \mathrm{~g} \mathrm{fat}, 396.14 \mathrm{kcal}$ of energy, and $13.16 \%$ water content; while based on chemical analysis it contains $13.47 \mathrm{~g}$ protein, $60.12 \mathrm{~g}$ carbohydrates, $16.82 \mathrm{~g}$ fats, $446.82 \mathrm{kcal}$ of energy, and $2.14 \%$ moisture content. The quality met the requirements of ISO No. 01-2973-1992 and higher than other cookies products on the market. Based on hedonic test, formulation 5 had the highest value in the terms of organoleptic test, nutritional content analysis, and cost analysis compared with other formulas. This cookies product already met the recommended reference. Persentage of cookies contribution for energy and protein respectively was $22.34 \%$ and $30.53 \%$.
\end{abstract}

Keywords: banana stone hump, cookies, corn, soybean, composite flour

\begin{abstract}
ABSTRAK
Tujuan penelitian adalah mempelajari formulasi tepung komposit dengan mengoptimalkan penggunaan bahan baku tanpa mengurangi mutu yang dihasilkan. Metode yang digunakan adalah penerapan linier programming. Faktor pembatas yang digunakan yaitu perbandingan bahan baku dari tepung komposit, nilai pembatas diambil dari SNI No. 01-2973-1992. Faktor kendala adalah harga bahan baku yang digunakan. Hasil penelitian tahap pertama menghasilkan karakteristik tepung yang sesuai dengan syarat mutu SNI. Analisis kimia untuk tepung jagung adalah karbohidrat sebesar $70,45 \%$, protein $8,96 \%$, kadar lemak 4,00 \% dan kadar air 3,14 \%; tepung kacang kedelai mengandung karbohidrat
\end{abstract}


sebesar 37,80 \%, protein 35,60\%, lemak 20,16\% dan kadar air 2,83\%; sedangkan tepung bonggol pisang batu mengandung karbohidrat sebesar 66,20 \%, protein 3,40\%, lemak 0,00\% dan kadar air 9,28\%. Hasil penelitian tahap kedua, dari lima formulasi yang feasible, didapatkan formulasi 5 sebagai formula optimal terpilih. Berdasarkan uji kesukaan, formulasi ini menghasilkan cookies dengan warna, aroma, rasa dan tekstur paling baik; berdasarkan hasil program linier dihasilkan biaya produksi terendah, yaitu Rp 1.734,400,- per 100 gram; serta berdasarkan analisis kandungan zat gizi, dari linier programming, formulasi 5 mengandung protein 6,80 gram, karbohidrat 55,03 gram, lemak 16,50 gram, energi 396,14 kkal, dan kadar air 13,16\%; sedangkan berdasarkan analisis kimia diperoleh protein 13,47 gram, karbohidrat 60,12 gram, lemak 16,82 gram, energi 446,82 kkal, dan kadar air 2,14 \%. Produk tersebut telah memenuhi syarat dari SNI No. 01-2973-1992 dan lebih tinggi dibanding produk cookies yang ada di pasaran. Berdasarkan uji hedonik, formulasi 5 mempunyai nilai tertinggi dari segi uji organoleptik, analisis kandungan gizi, serta analisis biaya dibanding dengan formula lainnya. Produk cookies terpilih sudah memenuhi acuan yang dianjurkan. Persentase sumbangan cookies adalah 22,34\% untuk energi dan 30,53\% untuk protein.

Kata kunci: bonggol pisang batu, cookies, jagung, kacang kedelai, tepung komposit

\section{PENDAHULUAN}

Cookies adalah kue manis berukuran kecil yang terbuat dari tepung gandum lunak, mengandung gula dan lemak tinggi, rendah air, dan bertekstur renyah (Lallemand). Cookies berasal dari kata koekje atau koekie yang berarti small cake atau bolu yang kecil (U.S. Wheat Association, 1983). Pada proses pembuatan dan bahan yang digunakan pada cookies tidak jauh berbeda dengan cake tetapi yang membedakan yaitu ukuran dan tingkat kekeringannya. Cookies yang baik memiliki beberapa karakteristik jika dilihat dari warna, tektur, rasa, aroma dan bahan yang digunakan tidak mengandung bahan cemaran logam maupun mikroba yang melebihi batas yang ditentukan (Departemen Perindustrian RI, 1990).

Bahan baku pembuatan cookies yaitu terigu yang berasal dari gandum. Permasalahannya adalah gandum merupakan komoditi impor dan dalam enam tahun terakhir ini harga gandum dunia cukup tinggi (Lopulalan, 2008). Oleh karenanya perlu diadakannya program diversifikasi pangan non pokok bernilai ekonomis rendah sekaligus memberikan efek fungsional. Upaya untuk mengurangi konsumsi terigu adalah dengan penggunaan tepung yang berbahan baku komoditas lokal yaitu tepung yang berasal dari jagung, kacang kedelai dan bonggol pisang batu.

Selama ini pemanfaatan bonggol pisang batu menjadi bahan olahan yang memiliki masa simpan relatif lama dan bernilai ekonomis tinggi masih sangat minim. Umumnya bonggol pisang hanya dimanfaatkan sebagai bibit tunas anakan baru. Menurut Munadjim (1998), pada zaman penjajah Belanda dan Jepang, bonggol pisang batu dimanfaatkan sebagai bahan makanan pengganti beras bagi yang kekurangan pangan.

Ditinjau dari segi potensinya, bonggol pisang batu dalam bentuk segar memiliki keunggulan kandungan karbohidrat yang tinggi, yaitu 11,6\% (Direktorat Gizi Departemen Kesehatan RI, 1992). Oleh karena itu, bonggol pisang batu juga berpotensi untuk diolah menjadi produk pangan setengah jadi, seperti tepung bonggol pisang batu. Tepung bonggol pisang adalah butiran halus yang lolos ayakan 80 mesh yang dihasilkan dari proses penggilingan gaplek bonggol pisang batu (Ardiyanto, 2008).

\section{METODE PENELITIAN}

\section{Bahan dan Alat Penelitian}

Bahan-bahan yang digunakan dalam percobaan ini adalah kacang kedelai varietas walet,bonggol pisang batu, jagung varietas jago, serta bahan baku penunjang yaitu garam, gula tepung, margarin, kuning telur, dan baking powder. Bahan-bahan kimia yang digunakan untuk analisis adalah aquades, $\mathrm{H}_{2} \mathrm{SO} 4, \mathrm{NaOH}$ $30 \%, \quad \mathrm{H}_{3} \mathrm{BO}_{3}, \quad \mathrm{~K}_{2} \mathrm{SO}_{4}, \mathrm{HgO}, \mathrm{HCl}$, pelarut Petroleum-Benzena, selenium black, metilen biru, dan batu didih.

Alat yang digunakan meliputi: stopwatch, spatula, kuas, termometer, sendok, pisau, talenan, mangkuk, rolling pin, loyang, 
ayakan 80 mesh, ayakan 100 mesh, baskom plastik, timbangan analitik, grinder, kompor gas, oven listrik dan oven blower, discmill. Alat-alat yang digunakan untuk analisis: kertas saring, pipet volume, cawan pengabuan dan cawan kadar air, tabung reaksi, erlenmeyer, mortir, bunsen, krustang, buret, batu didih, gelas piala, tanur, desikator, timbangan analitik, labu kjedahl, alat destilasi protein, kondensor, alat ekstraksi soxhlet, pendingin balik, penangas air, dan oven.

\section{Metode Penelitian}

Penelitian yang dilakukan terdiri dari tiga tahap, yaitu (1) Penelitian pertama, (2) Penelitian kedua dan (3) Penelitian ketiga.

\section{Penelitian Tahap Pertama}

Penelitian tahap pertama yang dilakukan adalah sebagai berikut:

1. Pembuatan tepung jagung, menggunakan prosedur pembuatan tepung jagung (Hubeis, 1984).

2. Pembuatan tepung kacang kedelai menggunakan prosedur pembuatan tepung kacang kedelai (Koswara 1992).

3. Pembuatan tepung bonggol pisang batu, menggunakan prosedur pembuatan tepung bonggol pisang batu (Ardiyanto, 2008)

Analisis komposisi kimia dilakukan dengan mengukur kadar air, kadar karbohidrat, kadar protein, kadar lemak dari Tepung Jagung, Tepung Kedelai, dan Tepung Bonggol Pisang Batu.

\section{Penelitian Tahap Kedua}

Pada penelitian tahap kedua dilakukan penentuan optimalisasi formula cookies menggunakan program Linier dengan bantuan data hasil analisis kimia dari tepung jagung, kacang kedelai dan bonggol pisang batu.bahan penunjang (gula, garam, susu skim, lemak/ mentega, baking powder, air, vanili dan telur) yang diperoleh dari survei langsung ke tiga pasar (pasar Swalayan "Yogya", pasar tradisional, dan warung) yang ada di Kota Bandung, serta faktor pembatas yang merupakan syarat gizi cookies dari SNI 01-4445-2002, serta dibandingkan dengan komposisi kimia yang terkandung dalam cookies yang ada di pasaran. Kemudian dibuat perbandingan formulasi tepung jagung, tepung kacang kedelai, dan tepung bonggol pisang batu sebagai pembatas bahan berubah dan sebagai pembatas bahan baku tetap, yaitu tepung gula $18,0 \%$, garam $0,01 \%$, susu skim $6,3 \%$, lemak/mentega $15,3 \%$, baking powder $0,02 \%$, vanili $0,01 \%$, air $5 \%$, telur $5 \%$.

Setelah diperoleh beberapa formula yang feasible, menurut program linier baik dari segi mutu maupun biaya, dari 25 formulasi yang telah diuji pada penelitian tahap kedua, bahwa panelis dapat menerima maksimal penambahan tepung jagung sebanyak 35\%, tepung kacang kedelai sebanyak $25 \%$, dan tepung bonggol pisang batu sebanyak 10\%, maka kemudian didapatkan 5 formulasi yang berdasarkan pada program linear dan uji hedonik. Formula feasibel tersebut digunakan sebagai bahan baku untuk membuat produk cookies pada penelitian tahap ketiga.

Adapun tahapan penentuan optimalisasi Formula Cookies tepung komposit dari Tepung Jagung, Kacang Kedelai dan Bonggol Pisang Batu diuraikan pada penelitian tahap ketiga.

\section{Penelitian Tahap Ketiga; Penentuan Simulasi dengan cara trial error menggunakan program linier}

Penentuan batas penambahan masingmasing tepung (jagung, kacang kedelai, dan bonggol pisang batu) dalam pembuatan cookies yang akan dibuat dilakukan secara trial error dari hasil terbaik 25 formulasi, kemudian didapatkan 5 formulasi yang berdasarkan pada program linear dan uji hedonik, Formula feasibel tersebut digunakan sebagai bahan baku untuk membuat produk cookies pada penelitian tahap ketiga. Formula I, II, III, IV, dan V kemudian diolah dengan menggunakan software WinQSB+ baik dari segi mutu maupun biaya.

Untuk kemudahan interpretasi model linier yang akan digunakan dalam penelitian ini, digunakan dasar perhitungan 100 gram adonan bakal cookies yang dibuat bagi penentuan fungsi tujuan maupun fungsi kendala. Program linier digunakan untuk 
menentukan biaya minimum dari model komposit bahan baku dalam pembuatan cookies tepung komposit dari tepung jagung, kacang kedelai, dan bonggol pisang batu, serta mutunya memenuhi syarat yang telah ditetapkan.

\section{HASIL DAN PEMBAHASAN}

\section{Analisis Kimia Tepung Jagung, Tepung Kacang Kedelai dan Tepung Bonggol Pisang Batu}

Sebelum digunakan sebagai tepung komposit dalam pembuatan cookies, terlebih dahulu dilakukan analisis proksimat terhadap komposisi tepung jagung, tepung kacang kedelai, dan tepung bonggol pisang batu (meliputi kadar air, lemak, dan protein), karena kandungan komponen kimia yang terdapat dalam bahan baku ini berpengaruh terhadap mutu produk cookies yang dihasilkan.

Data hasil analisis kimia bahan baku utama tersebut juga akan digunakan sebagai data input kandungan gizi yang pasti, untuk dimasukkan ke dalam program linear, sehingga data output yang dihasilkan merupakan formulasi yang optimal ditinjau dari segi kandungan gizi cookies yang dihasilkan. Hasil analisis kimia tersebut ditunjukkan pada Tabel 1.

Tabel 1. Hasil Analisis Kimia Bahan Baku Utama Tepung Komposit

\begin{tabular}{lcccc}
\hline Bahan & $\begin{array}{c}\text { Karbo- } \\
\text { hidrat } \\
(\%)\end{array}$ & $\begin{array}{c}\text { Protein } \\
(\%)\end{array}$ & $\begin{array}{c}\text { Lemak } \\
(\%)\end{array}$ & $\begin{array}{c}\text { Air } \\
(\%)\end{array}$ \\
\hline $\begin{array}{l}\text { Tepung Jagung } \\
\text { Tepung Kacang }\end{array}$ & $\begin{array}{l}74,50 \\
\text { Kedelai }\end{array}$ & 8,96 & 4,00 & 3,14 \\
$\begin{array}{l}\text { Tepung Bonggol } \\
\text { Pisang Batu }\end{array}$ & 6,20 & 35,60 & 20,16 & 2,83 \\
\hline
\end{tabular}

Tabel 1, menunjukkan bahwa dalam 100 gram tepung jagung memiliki kadar karbohidrat $74,50 \%$, protein $8,96 \%$, lemak $4,00 \%$, dan kadar air 3,14\%; sedangkan menurut (Hubeis, 2011), tepung jagung memiliki kadar karbohidrat sebesar 73,70\%, protein $9,26 \%$. Perbedaan kandungan kimia SNI dengan hasil analisis disebabkan oleh bahan baku yang digunakan dalam penelitian ini jenis dan varietasnya berbeda sehingga menghasilkan data yang berbeda, tetapi perbedaannya tidak terlalu menonjol. Begitu pun pada bahan baku utama tepung kacang kedelai.

Penurunan kadar protein disebabkan oleh adanya reaksi browning non-enzimatis, yaitu terjadinya reaksi antara asam organik dengan gula pereduksi, dan antara asam asam amino dengan gula pereduksi. Sedangkan reaksi asam organik dengan gula pereduksi dapat menurunkan kadar karbohidrat (Winarno, 1993).

Penurunan kadar pati (karbohidrat) disebabkan oleh suhu pengeringan yang terlalu tinggi, serta disebabkan oleh adanya perubahan perubahan kimia tertentu, yaitu terbentuknya dekstrin dari pati yang jika dikeringkan terbentuk bahan yang keras (massif) pada permukaan bahan (Winarno, 1993).

Tepung kacang kedelai memiliki kandungan air yang rentan terhadap serangan mikroba, yang dinyatakan dengan Aw, yaitu jumlah air bebas yang dapat digunakan oleh mikroorganisme untuk pertumbuhannya (Winarno, 1997).

\section{Formulasi Untuk Menentukan Cookies Feasible Dengan Program Linear}

Penelitian tahap kedua meliputi pembuatan cookies dengan jumlah 25 formulasi. Hasil analisis komposisi kimia bahan baku (kadar air, kadar protein, kadar lemak, dan kadar karbohidrat) digunakan sebagai nilai koefisien dari masing-masing variabel dalam pemodelan program linier. Selain itu, data yang dikumpulkan meliputi harga bahan utama (tepung jagung, kacang kedelai, dan bonggol pisang batu), dan bahan penunjang (tepung gula, garam, susu skim, lemak/mentega, baking powder, air, vanili dan telur) serta faktor pembatas yang merupakan syarat gizi cookies.

Harga bahan utama diperoleh dari konversi harga bahan dasar jagung, kacang kedelai dan bonggol pisang batu segar ditambah dengan biaya proses penepungan seperti listrik (pengeringan), penggilingan, dan perhitungan rendemen tepung yang dihasilkan. Sedangkan bahan penunjang diperoleh dari survei langsung ke tiga pasar (pasar Swalayan "Yogya", pasar tradisional, dan modern), yang ada di Kota Bandung. Sedangkan untuk 
pembatas diperoleh dari komposisi kimia yang terkandung dalam cookies dari SNI No. 012973-1992 serta dibandingkan dengan cookies yang ada di pasaran.

Tujuan dari penggunaan program linier adalah untuk menentukan formula cookies dan komposit tepung jagung, kacang kedelai dan bonggol pisang batu, agar dihasilkan cookies yang sesuai dengan SNI No. 01-2973-1992 serta dapat diterima oleh konsumen, dan harga yang relatif lebih murah dibandingkan harga cookies yang ada di pasaran.

\section{Optimalisasi dan Simulasi Dengan Cara Trial Error Menggunakan Program Linier}

Karakteristik produk akhir cookies dari komposit tepung jagung, kacang kedelai dan bonggol pisang batu ditentukan oleh beberapa faktor, yaitu proses yang diterapkan pada saat pengolahan, jenis bahan baku, dan formulasi komposisi bahan baku yang digunakan. Formulasi komposisi bahan baku yang digunakan sangat mempengaruhi karakteristik produk komposit yang dihasilkan, baik dari karakteristik indrawi ataupun kandungan gizi yang terdapat di dalam tepung komposit. Program linear dapat digunakan untuk menentukan formulasi yang optimum, yaitu dengan memaksimalkan kandungan gizi sesuai dengan syarat produk makanan campuran untuk umum yang telah ada di pasaran dan meminimalkan harga jual.

Untuk melihat kesukaan dan daya terima masyarakat yang diwakili oleh panelis terhadap cookies, kemudian dibuat produk cookies dalam bentuk keras dan cookies tidak begitu keras, dengan batas penambahan maksimum dari tepung komposit yang disukai oleh panelis; ternyata masyarakat lebih menyukai bentuk cookies keras dibanding dengan bentuk tidak begitu keras, sehingga untuk produk selanjutnya dibuat produk cookies yang keras untuk masyarakat.

Sebagai dasar untuk menguji formula feasible tersebut diterima tidaknya oleh konsumen, maka dibuat sebanyak 25 formula yang feasible menggunakan program linear, dengan perbandingan tepung komposit jagung, kacang kedelai, dan bonggol pisang batu, yaitu seperti yang terlihat pada Tabel 2.
Tabel 2. Formulasi Optimalisasi dan Simulasi

\begin{tabular}{ccccc}
\multicolumn{5}{c}{ Cookies } \\
Formula & Formula & Formula & Formula & Formula \\
1 & 2 & 3 & 4 & 5 \\
$15: 15: 20$ & $30: 5: 15$ & $30: 10: 10$ & $25: 20: 5$ & $35: 10: 5$ \\
\hline Formula & Formula & Formula & Formula & Formula \\
6 & 7 & 8 & 9 & 10 \\
$20: 20: 10$ & $15: 25: 10$ & $10: 30: 10$ & $5: 10: 35$ & $15: 5: 30$ \\
\hline Formula & Formula & Formula & Formula & Formula \\
11 & 12 & 13 & 14 & 15 \\
$10: 10: 30$ & $15: 10: 25$ & $20: 5: 25$ & $10: 15: 20$ & $20: 10: 20$ \\
\hline Formula & Formula & Formula & Formula & Formula \\
16 & 17 & 18 & 19 & 20 \\
$20: 15: 15$ & $10: 25: 15$ & $35: 5: 10$ & $30: 10: 10$ & $30: 15: 5$ \\
\hline Formula & Formula & Formula & Formula & Formula \\
21 & 22 & 23 & 24 & 25 \\
$10: 35: 5$ & $15: 30: 5$ & $25: 10: 15$ & $40: 5: 5$ & $5: 40: 5$ \\
\hline
\end{tabular}

\section{Keterangan:}

Urutan Rasio Tepung ( $\mathrm{T})$ Komposit $=$

(T. Jagung : T. Kacang Kedelai : T. Bonggol Pisang Batu)

Dari Tabel 2, dapat dilihat bahwa Formula 9 (5:10:35), Formula 10 (15:5:30), Formula 11 (10:10:30), Formula 12 (15:10:25), dan Formula 13 (20:5:25) adalah 5 formula yang terpilih karena memiliki harga yang terendah atau termurah dan kandungan yang sesuai dengan pembatas yang sudah dirancang pada program linear WinQSB dengan mengacu pada batasan SNI No. 01-2973-1992.

Pada tahap ini, formula cookies dari komposit tepung jagung, kacang kedelai dan bonggol pisang batu dari 5 formulasi terendah, masih tidak dapat diterima panelis dari segi organoleptik, dikarenakan jumlah bonggol pisang yang terlalu banyak. Selanjutnya dari hasil uji organoleptik meliputi warna, aroma, rasa, tekstur, dan kenampakan, didapatkan 5 formula terendah atau termurah kedua, yaitu Formula $14 \quad(10: 15: 20), \quad$ Formula 15 (20:10:20), Formula 1 (15:15:20), Formula 2 (30:5: 15), dan Formula 16 (20:15:15). Panelis masih tidak menyukai cookies yang dihasilkan dengan formulasi ini dikarenakan masih ada rasa sepat yang berasal dari tanin yang terkandung pada tepung bonggol pisang batu.

Selanjutnya diuji 15 formula terakhir, yaitu Formula 17, Formula 3, Formula 6, Formula 7, Formula 8, Formula 18, Formula 19, Formula 4, Formula 5, Formula 20, Formula 21, Formula 22, Formula 23, Formula 24, dan Formula 25. Hasil dari uji organoleptik tersebut menunjukkan bahwa formula cookies dari 
komposit tepung jagung, kacang kedelai dan bonggol pisang batu yang masih dapat diterirna oleh panelis adalah penambahan tepung jagung maksimal $35 \%$, hal ini dikarenakan rasa dan aroma dari tepung jagung yang lebih familiar dengan lidah masyarakat; penambahan tepung kacang kedelai maksimal 25\%, hal ini dikarenakan bau tepung kacang kedelai yang agak mengganggu rasa dan aroma cookies yang dihasilkan; dan penambahan tepung bonggol pisang batu maksimal 10\%, hal ini dikarenakan adanya rasa sepat dari bonggol pisang batu yang berasal dari tanin yang tidak hilang selama pengolahan bonggol pisang batu hingga menjadi tepung.

\section{Penentuan Simulasi Dengan Cara trial error menggunakan Program Linier.}

Penentuan simulasi dan optimalisasi formula tepung komposit dari jagung, kacang kedelai, dan bonggol pisang batu dilakukan secara trial error dengan menggunakan program linier dengan beberapa factor pembatas, yaitu pembatas kalori, protein, karbohidrat, lemak dan kadar air, serta pembatas jumlah penggunaan tepung dari komposit jagung, kacang kedelai, dan bonggol pisang batu; sehingga fungsi tujuan berupa minimisasi harga dapat tercapai dengan kandungan kalori, protein, karbohidrat, lemak dan kadar air cookies sesuai SNI No. 01-2973-1992.

Setelah dilakukan triar error dengan menggunakan program WinQSB + versi 2.0, didapat beberapa formula yang feasible menurut program linier baik dari segi mutu maupun biaya. Kemudian formula feasibel tersebut digunakan sebagai bahan baku untuk membuat produk cookies didapatkan 5 formulasi dengan mengacu pada tahap kedua, yaitu optimalisasi dan simulasi.

\section{Pembuatan Produk Cookies Terpilih}

Penambahan maksimal dari tepung komposit dijadikan sebagai acuan menentukan formula cookies selanjutnya yang akan diuji oleh panelis-agak-terlatih (mahasiswa teknologi pangan) sebanyak 15 orang. Tidak dipakainya panelis-masyarakat-biasa agar data yang didapatkan lebih kuat dan lebih terarah, karena mahasiswa teknologi pangan termasuk sudah agak terlatih dalam melakukan uji. Untuk selanjutnya dibuat lima buah formulasi tepung campuran yang feasible, yang dijadikan acuan dalam pembuatan cookies pada penelitian tahap kedua.

Berdasarkan pertimbangan rasa yang disukai, batas maksimal tepung komposit yang digunakan pada pengujian rasa, yaitu maksimal tepung jagung sebesar 35\%, tepung kacang kedelai sebesar $25 \%$, dan tepung bonggol pisang batu sebesar 10\%; selanjutnya dibuat lima formulasi yang disukai dan feasible. Jumlah tepung bonggol pisang batu yang ditambahkan pada tepung komposit yaitu sebesar 10 gram, dengan jumlah yang tetap untuk semua formulasi; bertujuan untuk menekan harga, kandungan gizi sesuai SNI, dan tetap disukai masyarakat karena rasa sepat tidak banyak dan panelis tidak terganggu dengan rasa sepat yang ditimbulkan. Jumlah tepung jagung digunakan sebesar 15 gram hingga 35 gram; jumlah yang bertambah bertujuan untuk meminimalkan harga karena penggunaan kedelai akan menurun, kandungan gizi sesuai SNI, dan disukai masyarakat. Sedangkan jumlah tepung kacang kedelai sebesar 25 gram hingga 5 gram; jumlah yang menurun karena harga yang tinggi atau mahal, kedelai juga merupakan komoditas impor, panelis pun agak terganggu dengan aroma kedelai bila terlalu banyak, dan agar harga dapat lebih minimal, sesuai dengan tujuan penggunaan aplikasi program linear WinQSB, yaitu meminimumkan harga.

Adapun hasil yang diperoleh adalah Formula 1 (15\% tepung jagung, 25\% tepung kacang kedelai, dan $10 \%$ tepung bonggol pisang batu), Formula 2 (20\% tepung jagung, $20 \%$ tepung kacang kedelai, dan $10 \%$ tepung bonggol pisang batu), Formula 3 (25\% tepung jagung, $15 \%$ tepung kacang kedelai, dan $10 \%$ tepung bonggol pisang batu), dan Formula 4 (30\% tepung jagung, $10 \%$ tepung kacang kedelai, dan $10 \%$ tepung bonggol pisang batu), Formula 5 (35\% tepung jagung, 5\% tepung kacang kedelai, dan $10 \%$ tepung bonggol pisang batu). Untuk lebih jelasnya dapat dilihat pada Tabel 3. 
Tabel 3. Formulasi cookies dari komposit Tepung Jagung, Tepung Kacang Kedelai dan Tepung Bonggol Pisang Batu

\begin{tabular}{clccccc}
\hline \multirow{2}{*}{ Jenis } & \multirow{2}{*}{ Bahan Baku } & \multicolumn{5}{c}{ Formula Optimal } \\
\cline { 3 - 7 } Produk & & $\mathbf{1}$ & $\mathbf{2}$ & $\mathbf{3}$ & $\mathbf{4}$ & $\mathbf{5}$ \\
\hline Cookies & Tepung Jagung $\left(\mathrm{X}_{1}\right)$ & 15 & 20 & 25 & 30 & 35 \\
& T. Kacang Kedelai $\left(\mathrm{X}_{2}\right)$ & 25 & 20 & 15 & 10 & 5 \\
& T. Bonggol Pisang $\left(\mathrm{X}_{3}\right)$ & 10 & 10 & 10 & 10 & 10 \\
& Tepung Gula $\left(\mathrm{X}_{4}\right)$ & 18 & 18 & 18 & 18 & 18 \\
& Susu Skim $\left(\mathrm{X}_{5}\right)$ & 6,3 & 6,3 & 6,3 & 6,3 & 6,3 \\
& Garam $\left(\mathrm{X}_{6}\right)$ & 0,1 & 0,1 & 0,1 & 0,1 & 0,1 \\
& Air $\left(\mathrm{X}_{7}\right)$ & 5,0 & 5,0 & 5,0 & 5,0 & 5,0 \\
& Lemak/mentega $\left(\mathrm{X}_{8}\right)$ & 15,3 & 15,3 & 15,3 & 15,3 & 15,3 \\
& Baking Powder $\left(\mathrm{X}_{9}\right)$ & 0,2 & 0,2 & 0,2 & 0,2 & 0,2 \\
& Vanili $\left(\mathrm{X}_{10}\right)$ & 0,1 & 0,1 & 0,1 & 0,1 & 0,1 \\
Telur $\left(\mathrm{X}_{11}\right)$ & 5,0 & 5,0 & 5,0 & 5,0 & 5,0 \\
\hline JUMLAH BAHAN & $\mathbf{1 0 0}$ & $\mathbf{1 0 0}$ & $\mathbf{1 0 0}$ & $\mathbf{1 0 0}$ & $\mathbf{1 0 0}$ \\
\end{tabular}

Formulasi yang dihasilkan dari program linier merupakan formula optimal dengan kandungan kalori, protein, dan kadar air yang memenuhi standar pembatas yang telah ditetapkan serta memiliki harga terendah. Selain dibatasi oleh pembatas kandungan gizi, formula yang dihasilkan juga memenuhi standar pembatas bahan baku. Bahan baku yang digunakan terdiri dari dua jenis, yaitu pembatas bahan-baku tetap dan pembatas bahan-baku berubah. Pembatas bahan baku tetap adalah tepung gula, garam, susu skim, lemak/mentega, baking powder, vanili, air, telur; sedangkan pembatas bahan-baku berubah adalah tepung jagung, tepung kacang kedelai dan tepung bonggol pisang batu.

Batas penambahan tepung jagung, kacang kedelai, dan tepung bonggol pisang batu dalam pembuatan cookies terlihat dari beberapa formula yang feasible, yaitu Formula 1, 2, 3, 4 dan formula 5. Untuk memudahkan interpretasi model linier yang digunakan dalam penelitian ini digunakan dasar perhitungan 100 gram adonan bakal cookies yang dibuat bagi penentuan fungsi tujuan maupun fungsi kendala.

Informasi biaya dari bahan $\left(\mathrm{C}_{\mathrm{i}}\right)$ yang digunakan dalam pembuatan cookies pada model pencampuran bahan-bahan baku dengan penyelesaian program linier adalah tepung jagung $\left(\mathrm{X}_{1}\right) \mathrm{Rp} 14,0,-\mathrm{g}$, tepung kacang kedelai $\left(\mathrm{X}_{2}\right)$ Rp 29,0,-/g, tepung bonggol pisang batu $\left(\mathrm{X}_{3}\right) \mathrm{Rp} 7,-/ \mathrm{g}$, tepung gula $\left(\mathrm{X}_{4}\right) \mathrm{Rp} 14,0,-/ \mathrm{g}$, Susu Skim $\left(X_{5}\right) \operatorname{Rp} 50,0,-/ g$, garam $\left(X_{6}\right) \operatorname{Rp} 4,0$,/g, air $\left(\mathrm{X}_{7}\right) \mathrm{Rp} 1,5,-/ \mathrm{g}$, lemak/mentega $\left(\mathrm{X}_{8}\right) \mathrm{Rp}$ 25,0,-/g, baking powder $\left(\mathrm{X}_{9}\right) \mathrm{Rp} 35,0,-/ \mathrm{g}$, vanili $\left(X_{10}\right)$ Rp 50,0,-/g,.dan telur $\left(X_{i}\right.$ Rp 12,0,-/g. Dalam permasalahan ini bahan baku yaitu tepung jagung, kacang kedelai dan bonggol pisang batu dianggap sebagai peubah keputusan (faktor $\mathrm{X}_{\mathrm{j}}$ ), dimana diasumsikan bahwa air merupakan sumber daya yang terbatas sehingga perlu dilakukan minimisasi biaya bahan baku yang digunakan yang dinyatakan dalam bentuk fungsi tujuan berikut:

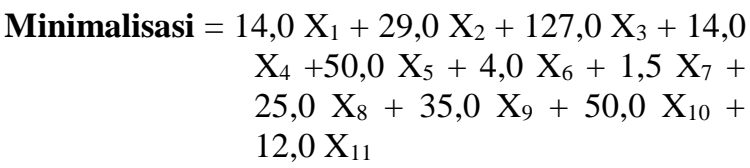

Bahan baku $\left(b_{\mathrm{j}}\right)$ yang digunakan, yaitu tepung jagung, tepung kacang kedelai, dan tepung bonggol pisang batu harus dibatasi dalam jumlah tertentu untuk menekan biaya produksi. Selain itu, cookies yang dihasilkan karakteristiknya diharapkan dapat diterima oleh konsumen dan memenuhi standar kadar kalori, protein, dan kadar air yang terkandung dalam cookies.

Batasan yang digunakan untuk menyusun fungsi atau persamaan kendala adalah jumlah tepung jagung, tepung kacang kedelai, dan tepung bonggol pisang batu yang dicampurkan dalam pembuatan cookies dengan pembatas kadar karbohidrat minimal $70 \%$, kadar protein minimal $6 \%$, kadar lemak $10 \%$, dan kadar air maksimal 5\%, kalori minimal $39 \%$. Sedangkan bahan baku lainnya seperti tepung gula $18,0 \%$, garam $0,01 \%$, susu skim $6,3 \%$, lemak/mentega $15,3 \%$, baking powder $0,02 \%$, vanili $0,01 \%$, air $5 \%$, telur $5 \%$, merupakan bahan baku tetap atau bahan baku yang merupakan tidak peubah keputusan.

Bentuk fungsi pembatas kebutuhan pembuatan cookies ini adalah:

1. Fungsi Kendala jumlah bahan baku total: $\mathrm{X}_{1}+\mathrm{X}_{2}+\mathrm{X}_{3}+\mathrm{X}_{4}+\mathrm{X}_{5}+\mathrm{X}_{6}+\mathrm{X}_{7}+\mathrm{X}_{8}+\mathrm{X}_{9}+$ $X_{10}+X_{11}=100 \%$ (100 gram)

2. Pembatas Lemak minimal $10 \%$ $a_{11} X_{1}+a_{21} X_{2}+a_{31} X_{3} a_{41} X_{4}+a_{51} X_{5}+a_{61} X_{6}+$ 
$a_{71} X_{7}+a_{81} X_{8}+a_{91} X_{9}+a_{101} X_{10}+a_{111} X_{11} \geq b_{1}$ $\left(X_{1}+X_{2}+X_{3}+X_{4}+X_{5}+X_{6}+X_{7}+X_{8}+\right.$ $\left.\mathrm{X}_{9}+\mathrm{X}_{10}+\mathrm{X}_{11}\right)$

$0,057862 X_{1}+0,172601 X_{2}+0,7407325 X_{3}$ $+0 X_{4}+0,356 X_{5}+0 X_{6}+0 X_{7}+0,005 X_{8}$ $+0 X_{9}+0 X_{10}+0,163 X_{11} \geq 0,1$

3. Pembatas Protein minimal $6 \%$

$$
\begin{aligned}
& a_{12} X_{1}+a_{22} X_{2}+a_{32} X_{3}+a_{42} X_{4}+a_{52} X_{5}+ \\
& a_{62} X_{6}+a_{72} X_{7}+a_{82} X_{8}+a_{92} X_{9}+a_{102} X_{10}+ \\
& a_{112} X_{11} \geq b_{2}\left(X_{1}+X_{2}+X_{3}+X_{4}+X_{5}+\right. \\
& \left.X_{6}+X_{7}+X_{8}+X_{9}+X_{10}+X_{11}\right) \\
& 0,047480 X_{1}+0,3308015 X_{2}+0,0830105 \\
& X_{3}+0 X_{4}+0,01 X_{5}+0 X_{6}+0 X_{7}+ \\
& 0,816 X_{8}+0 X_{9}+0 X_{10}+0,319 X_{11} \geq \\
& 0,06
\end{aligned}
$$

4. Pembatas karbohidrat minimal $70 \%$

$$
\begin{aligned}
& a_{13} X_{1}+a_{23} X_{2}+a_{33} X_{3}+a_{43} X_{4}+a_{53} X_{5}+ \\
& a_{63} X_{6}+a_{73} X_{7}+a_{83} X_{8}+a_{93} X_{9}+a_{103} X_{10}+ \\
& a_{113} X_{11} \geq b_{3}\left(X_{1}+X_{2}+X_{3}+X_{4}+X_{5}+X_{6}\right. \\
& \left.+X_{7}+X_{8}+X_{9}+X_{10}+X_{11}\right) \\
& 0,704592 X_{1}+0,3473405 X_{2}+0 X_{3}+ \\
& 0,94 X_{4}+0,52 X_{5}+0 X_{6}+0 X_{7}+0,014 \\
& X_{8}+0 X_{9}+0 X_{10}+0,007 X_{11} \geq 0,70
\end{aligned}
$$

5. Pembatas kadar air maksimal $5 \%$

$$
\begin{aligned}
& a_{14} X_{1}+a_{24} X_{2}+a_{34} X_{3}+a_{44} X_{4}+a_{54} X_{5}+a_{64} X_{6} \\
& +a_{74} X_{7}+a_{84} X_{8}+a_{94} X_{9}+a_{104} X_{10}+a_{114} X_{11} \geq \\
& b_{4}\left(X_{1}+X_{2}+X_{3}+X_{4}+X_{5}+X_{6}+X_{7}+X_{8}\right. \\
& \left.+X_{9}+X_{10}+X_{11}\right) \\
& 0,0314385 X_{1}+0,0013805 X_{2}+0,0193475 \\
& X_{3}+0,054 X_{4}+0,035 X_{5}+0,01 X_{6}+0 X_{7} \\
& +0,16 X_{8}+0,03 X_{9}+0,03 X_{10}+0,494 X_{11} \\
& \geq 0,05
\end{aligned}
$$

Pembatas minimal tepung jagung, tepung kacang kedelai, dan tepung bonggol pisang batu untuk kelima formulasi cookies dan pembatas bahan baku tetap seperti yang ditunjukkan pada tabel di bawah ini. Fungsi tujuan dan fungsi kendala atau fungsi pembatas minimal tepung jagung, tepung kacang kedelai, dan tepung bonggol pisang batu yang dibentuk dalam menyelesaikan model pencampuran antara tepung jagung, tepung kacang kedelai, dan tepung bonggol pisang batu yang optimal dalam pembuatan cookies sebanyak 100 gram untuk mendapatkan biaya minimum dari kelima formula dapat dilihat pada Tabel 4, 5, 6, 7 dan 8 .

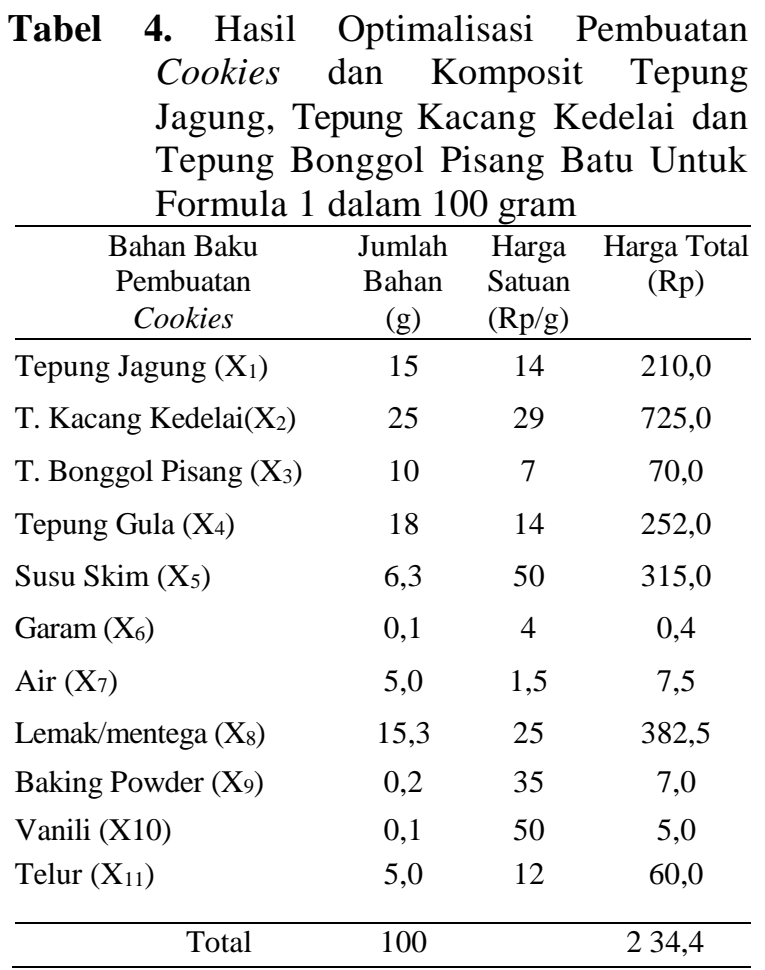

Tabel 5. Hasil Optimalisasi Pembuatan Cookies dan Komposit Tepung Jagung, Tepung Kacang Kedelai dan Tepung Bonggol Pisang Batu untuk Formula 2 dalam 100 gram

\begin{tabular}{lccr}
\hline \multicolumn{1}{c}{$\begin{array}{c}\text { Bahan Baku } \\
\text { Pembuatan } \\
\text { Cookies }\end{array}$} & $\begin{array}{c}\text { Jumlah } \\
\text { Bahan } \\
(\mathrm{g})\end{array}$ & $\begin{array}{c}\text { Harga } \\
\text { Satuan } \\
(\mathrm{Rp} / \mathrm{g})\end{array}$ & $\begin{array}{c}\text { Harga Total } \\
(\mathrm{Rp})\end{array}$ \\
\hline Tepung Jagung $\left(\mathrm{X}_{1}\right)$ & 20 & 14 & 280,0 \\
T. Kacang Kedelai $\left(\mathrm{X}_{2}\right)$ & 20 & 29 & 580,0 \\
T. Bonggol Pisang $\left(\mathrm{X}_{3}\right)$ & 10 & 7 & 70,0 \\
Tepung Gula $\left(\mathrm{X}_{4}\right)$ & 18 & 14 & 252,0 \\
Susu Skim $\left(\mathrm{X}_{5}\right)$ & 6.3 & 50 & 315,0 \\
Garam $\left(\mathrm{X}_{6}\right)$ & 0.1 & 4 & 0,4 \\
Air $\left(\mathrm{X}_{7}\right)$ & 5.0 & 1,5 & 7,5 \\
Lemak/mentega $\left(\mathrm{X}_{8}\right)$ & 15.3 & 25 & 382,5 \\
Baking Powder $\left(\mathrm{X}_{9}\right)$ & 0.2 & 35 & 7,0 \\
Vanili $\left(\mathrm{X}_{10}\right)$ & 0.1 & 50 & 5,0 \\
Telur $\left(\mathrm{X}_{11}\right)$ & 5.0 & 12 & 60,0 \\
\hline \multicolumn{1}{c}{ Total } & 100 & & 1959,4 \\
\hline
\end{tabular}


Tabel 6. Hasil Optimalisasi Pembuatan Cookies dan Komposit Tepung Jagung, Tepung Kacang Kedelai dan Tepung Bonggol Pisang Batu Untuk Formula 3 dalam 100 gram

\begin{tabular}{lccr}
\hline \multicolumn{1}{c}{$\begin{array}{c}\text { Bahan Baku } \\
\text { Pembuatan }\end{array}$} & $\begin{array}{c}\text { Jumlah } \\
\text { Bahan } \\
(\mathrm{g})\end{array}$ & $\begin{array}{c}\text { Harga } \\
\text { Satuan } \\
(\mathrm{Rp} / \mathrm{g})\end{array}$ & $\begin{array}{c}\text { Harga Total } \\
(\mathrm{Rp})\end{array}$ \\
\hline Tepung Jagung $\left(\mathrm{X}_{1}\right)$ & 25 & 14 & 350,0 \\
T. Kacang Kedelai $\left(\mathrm{X}_{2}\right)$ & 15 & 29 & 435,0 \\
T.Bonggol Pisang $\left(\mathrm{X}_{3}\right)$ & 10 & 7 & 70,0 \\
Tepung Gula $\left(\mathrm{X}_{4}\right)$ & 18 & 14 & 252,0 \\
Susu Skim $\left(\mathrm{X}_{5}\right)$ & 6,3 & 50 & 315,0 \\
Garam $\left(\mathrm{X}_{6}\right)$ & 0,1 & 4 & 0,4 \\
Air $\left(\mathrm{X}_{7}\right)$ & 5,0 & 1,5 & 7,5 \\
Lemak/mentega $\left(\mathrm{X}_{8}\right)$ & 15,3 & 25 & 382,5 \\
Baking Powder $\left(\mathrm{X}_{9}\right)$ & 0,2 & 35 & 7,0 \\
Vanili $\left(\mathrm{X}_{10}\right)$ & 0,1 & 50 & 5,0 \\
Telur $\left(\mathrm{X}_{11}\right)$ & 5,0 & 12 & 60,0 \\
\hline \multicolumn{1}{c}{ Total } & 100 & & 1884,4 \\
\hline
\end{tabular}

Tabel 7. Hasil Optimalisasi Pembuatan Cookies dan Komposit Tepung Jagung, Tepung Kacang Kedelai, dan Tepung Bonggol Pisang Batu untuk Formula 4 dalam 100 gram

\begin{tabular}{lccr}
\hline \multicolumn{1}{c}{$\begin{array}{c}\text { Bahan Baku } \\
\text { Pembuatan }\end{array}$} & $\begin{array}{c}\text { Jumlah } \\
\text { Bahan } \\
(\mathrm{g})\end{array}$ & $\begin{array}{c}\text { Harga } \\
\text { Satuan } \\
(\mathrm{Rp} / \mathrm{g})\end{array}$ & $\begin{array}{c}\text { Harga Total } \\
(\mathrm{Rp})\end{array}$ \\
\hline Tepung Jagung $\left(\mathrm{X}_{1}\right)$ & 30 & 14 & 420,0 \\
T. Kacang Kedelai( $\left.\mathrm{X}_{2}\right)$ & 10 & 29 & 290,0 \\
T.Bonggol Pisang $\left(\mathrm{X}_{3}\right)$ & 10 & 7 & 70,0 \\
Tepung Gula $\left(\mathrm{X}_{4}\right)$ & 18 & 14 & 252,0 \\
Susu Skim $\left(\mathrm{X}_{5}\right)$ & 6.3 & 50 & 315,0 \\
Garam $\left(\mathrm{X}_{6}\right)$ & 0.1 & 4 & 0,4 \\
Air $\left(\mathrm{X}_{7}\right)$ & 5.0 & 1,5 & 7,5 \\
Lemak/mentega $\left(\mathrm{X}_{8}\right)$ & 15.3 & 25 & 382,5 \\
Baking Powder $\left(\mathrm{X}_{9}\right)$ & 0.2 & 35 & 7,0 \\
Vanili $\left(\mathrm{X}_{10}\right)$ & 0.1 & 50 & 5,0 \\
Telur $\left(\mathrm{X}_{11}\right)$ & 5.0 & 12 & 60,0 \\
\hline \multicolumn{1}{c}{ Total } & 100 & & 1809,4 \\
\hline
\end{tabular}

Tabel 8. Hasil Optimalisasi Pembuatan Cookies dan Komposit Tepung Jagung, Tepung Kacang Kedelai dan Tepung Bonggol Pisang Batu untuk Formula 5 dalam 100 gram

\begin{tabular}{lccr}
\hline \multicolumn{1}{c}{$\begin{array}{c}\text { Bahan Baku } \\
\text { Pembuatan } \\
\text { Cookies }\end{array}$} & $\begin{array}{c}\text { Jumlah } \\
\text { Bahan } \\
(\mathrm{g})\end{array}$ & $\begin{array}{c}\text { Harga } \\
\text { Satuan } \\
(\mathrm{Rp} / \mathrm{g})\end{array}$ & $\begin{array}{c}\text { Harga Total } \\
(\mathrm{Rp})\end{array}$ \\
\hline Tepung Jagung $\left(\mathrm{X}_{1}\right)$ & 35 & 14 & 490,0 \\
T. Kacang Kedelai $\left(\mathrm{X}_{2}\right)$ & 5 & 29 & 145,0 \\
T.Bonggol Pisang $\left(\mathrm{X}_{3}\right)$ & 10 & 7 & 70,0 \\
Tepung Gula $\left(\mathrm{X}_{4}\right)$ & 18 & 14 & 252,0 \\
Susu Skim $\left(\mathrm{X}_{5}\right)$ & 6,3 & 50 & 315,0 \\
Garam $\left(\mathrm{X}_{6}\right)$ & 0,1 & 4 & 0,4 \\
Air $\left(\mathrm{X}_{7}\right)$ & 5,0 & 1,5 & 7,5 \\
Lemak/mentega $\left(\mathrm{X}_{8}\right)$ & 15,3 & 25 & 382,5 \\
Baking Powder $\left(\mathrm{X}_{9}\right)$ & 0,2 & 35 & 7,0 \\
Vanili $\left(\mathrm{X}_{10}\right)$ & 0,1 & 50 & 5,0 \\
Telur $\left(\mathrm{X}_{11}\right)$ & 5,0 & 12 & 60,0 \\
\hline \multicolumn{1}{c}{ Total } & 100 & & 1734,4 \\
\hline
\end{tabular}

Tabel 4, 5, 6, 7 dan 8 menunjukan formula 5 lebih layak (feasible) dari formula 1, 2, 3 dan 4 dengan penggunaan tepung jagung $35 \%$, tepung kacang kedelai 5\%, dan tepung bonggol pisang batu $10 \%$. Hal ini dikarenakan jumlah penggunaan tepung kacang kedelai lebih sedikit dari formula 1, 2, 3 dan 4, sehingga memberikan harga 100 gram cookies lebih rendah atau lebih murah dari cookies lain yang dihasilkan, yaitu: Formula 5 sebesar Rp 1.734,400,- sedangkan Formula 1 sebesar Rp 2.034,400,-; Formula 2 sebesar Rp 1.959,400,-; Formula 3 sebesar Rp 1.884,400,-; dan formula 4 sebesar Rp 1.809,400,-. Tetapi, penggunaan tepung jagung pada formula 5 lebih tinggi dibanding Formula 4, 3, 1 dan 1. Sedangkan penambahan tepung kacang kedelai paling tinggi pada Formula 1, 2, 3 dan 4.

\section{KESIMPULAN DAN SARAN}

\section{Kesimpulan}

1. program linier dapat digunakan untuk menentukan formula cookies dan komposit tepung jagung, kacang kedelai, dan bonggol pisang batu, agar dihasilkan cookies yang sesuai dengan SNI No. 01-2973-1992 serta dapat diterima oleh konsumen, dan harga 
yang relatif lebih murah dibandingkan harga cookies yang ada di pasaran.

2. Formula $9 \quad(5: 10: 35)$, Formula 10 (15:5:30), Formula 11 (10:10:30), Formula 12 (15:10:25), dan Formula 13 (20:5:25), adalah 5 formula yang terpilih berdasarkan harga yang terendah atau termurah dan kandungan sesuai SNI.

3. Hasil program linier menunjukkan formula 5 lebih layak (feasible) dari formula 1, 2, 3 dan 4 dengan penggunaan tepung jagung $35 \%$, tepung kacang kedelai $5 \%$, dan tepung bonggol pisang batu $10 \%$.

\section{Saran}

Berdasarkan hasil penelitian yang telah dilakukan dapat direkomendasikan saran bahwa perlu dibuat variasi produk dan flavour dari tepung komposit jagung, kacang kedelai, dan bonggol pisang batu agar tersedia pilihan makanan untuk masyarakat.

\section{DAFTAR PUSTAKA}

Ardiyanto, Y. 2008. Mempelajari Karakteristik Fisikokimia Tepung Bonggol Pisang Batu (Musa brachycarph) dan Kapas (Musa paradisiaca var forma tipica). Skripsi. Fakultas Teknologi Industri Pertanian, Unpad, Jatinangor.

Departemen Perindustrian RI. 1990. Standar Industri Indonesia Nomor 0177. Mutu dan Cara Uji Cookies. Departemen Perindustrian.
Dewan Standardisasi Nasional. 1992. SNI N0. 01-2973-1992. Mutu dan Cara Uji Cookies. Jakarta.

Direktorat Gizi Departemen Kesehatan RI. 1992. Daftar Komposisi Bahan Makanan. Bharata Karya Aksara, Jakarta.

Hubeis, M. 1984. Pengantar Pengolahan Tepung Serealia dan Biji-bijian. Diktat Kuliah Jurusan Teknologi Pangan dan Gizi. Fakultas Teknologi Pertanian, IPB, Bogor.

Koswara, S. 1992. Teknologi Pengolahan Kedelai menjadikan Makanan Bermutu. Pustaka Sinar Harapan, Jakarta.

Lopulalan, C.G.C. 2008. Kajian Formulasi dan Isothermis Sorpsi Air Biskuit Jagung. Thesis. IPB, Bogor.

Munadjim. 1983. Teknologi Pengolahan Pisang. PT. Gramedia Pustaka Utama, Jakarta.

U.S. Wheat Association. 1983. Pedoman Pembuatan Roti dan Kue. Djambatan, Jakarta.

Winarno, F.G. 1997. Kimia Pangan dan Gizi. PT. Gramedia Pustaka Utama, Jakarta. 